\title{
ADVERSE HEALTH EFFECTS OF INDOOR MOULDS
}

\author{
Elena PIECKOVÁ \\ Slovak Medical University, Bratislava, Slovakia \\ Received in February 2012 \\ CrossChecked in August 2012 \\ Accepted in October 2012
}

\begin{abstract}
Building associated illnesses - sick building syndrome (SBS) as a common example - are associated with staying in buildings with poor indoor air quality. The importance of indoor fungal growth in this phenomenon continues to be evident, even though no causative relation has been established so far. Indoor humidity is strongly associated with the symptoms of SBS. Fungal metabolites that may induce ill health in susceptible occupants comprise beta-D-glucan, mycotoxins, and volatile organic compounds as known irritants and/or immunomodulators. Indoor toxic fungal metabolites might be located in micromycetal propagules (endometabolites), in (bio-)aerosol, detritus, and house dust (exometabolites) as their particular carriers. It is highly probable that hyphal fragments, dust, and particles able to reach the alveoli have the strongest depository and toxic potential. Most fungal spores are entrapped by the upper respiratory tract and do not reach further than the bronchi because of their size, morphology, and the mode of propagation (such as slime heads and aggreggation). This is why studies of the toxic effects of fungal spores prefer directly applying metabolite mixtures over mimicking real exposure. Chronic low-level exposure to a mixture of fungal toxicants and other indoor stressors may have synergistic effects and lead to severe neuroendocrineimmune changes.
\end{abstract}

KEY WORDS: inflammation, mycotoxins, respiratory tract, sick building syndrome, volatile organic compounds

Different indoor factors (such as chemicals, microorganisms, allergens, and tobacco smoke) can contribute to many building-related illnesses (BRI) in exposed occupants. These include infections related to building ventilation (legionellosis), common cold, flu or, reactions to indoor chemicals, fungi, bacteria, and/or their toxins. A type of BRI known as sick building syndrome (SBS) includes a complex of health complaints and general discomfort $(1,2)$. Symptoms of SBS are non-specific and usually depend on indoor microclimatic parameters such as temperature, relative humidity, dust, cigarette smoke, ventilation, building

\footnotetext{
* The subject of this article has partly been presented at the Internationa Symposium "Power of Fungi and Mycotoxins in Health and Disease" held in Primošten, Croatia, from 19 to 22 October 2011
}

materials and furnishing, and sensibility of affected persons. Inflammatory reactions to indoor toxicants are either local - in the airways, mediated by $\operatorname{IgE}$ (allergic mechanism) or by non-specific inflammation (e. g. cytotoxic effects) - or systemic through the release of lung cytokines (3). The role of fungi in the aetiology of health problems associated with staying in certain buildings has not been fully clarified. Indoor fungal exposure may lead to allergies such as fungal rhinitis, hypersensitivity pneumonia, and/or asthma $(4,5)$. Monitoring exposure to indoor fungi is rather complicated due to a lack of standard methods to evaluate how indoor microclimate, outdoor environment, and microscopic fungi affect each other. The ability of Penicillium sp. and Aspergillus sp., the so-called first colonisers, to grow on common house 
dust at relative humidity of $76 \%$ to $80 \%$ can probably explain why they prevail even in healthy buildings. Secondary colonisers (Cladosporium sp., Alternaria sp., Chaetomium sp.) that grow at $85 \%$ relative humidity and tertiary colonisers (Fusarium sp., Acremonium sp., yeasts) that grow at $>90 \%$ humidity are able to biodeteriorate any building material under optimal growth conditions (6-8).

\section{MYCOTOXINS, VOLATILES, AND HAEMOLYSINS}

Currently, a general approach to the study of the mechanism of fungal effects on human beings is becoming more urgent. Such an approach includes the immunosuppressive influence and (bioaerosoloic) inflammatory reactions to beta-glucans from fungal cell wall as well as toxic and irritative effects of their toxic exo- and endometabolites - mycotoxins and/or volatile organic compounds, and pathological conditions associated with fungal haemolysins (9). Regarding mycotoxins with rather well characterised toxicity (incl. carcino-, muta-, teratogenicity, cytotoxicity and immunosuppression) after ingestion or dermal exposure, an adverse biological effect can be caused by the inhalation of a dose at the minimum level of one tenth of the alimentary one. Indoor mycotoxins and their health effects have joined the most studied public health issues (10).

Microbial volatile organic compounds (MVOCs) such as alcohols, aldehydes, ketones, aromatic compounds, amines, terpenes, chlorinated hydrocarbons, and sulphuric compounds, (at indoor concentrations as high as $250 \mathrm{mg} \mathrm{m}^{-3}$ ) cause typical mouldy odour (usually 2-octen-1-ol or geosmine), but also an irritation, swelling/inflammation of the airways in sensitive people, and/or cytotoxic effects (DNA damage). These effects are associated with invisible moulds usually growing under wallpaper, carpets, or mattresses. The most common MVOCs are xylene, toluene, 2-propanol, limonen, heptane, formaldehyde, and acetaldehyde. There is a positive correlation between MVOC production and the ability of fungi to synthesise mycotoxins. According to Larsen et al. (11) and Corpi et al. (12), Aspergillus spp., A. versicolor, Cladosporium spp. and Penicillium spp. are the strongest producers of such compounds, e. g. 2-ethylhexanol, cyclohexane (skin and/or mucose irritation), and carcinogenic benzene.
Although, many occupational pulmonary mycotoxicoses have been reported as adverse effects of inhaled organic dust contaminated by microbial toxins (13), there is no objective evidence of clinical diseases caused by indoor mycotoxins alone, produced by Aspergillus sp., Penicillium sp., Fusarium sp., Trichoderma sp. and Stachybotrys chartarum, as no serious epidemiological study has addressed the issue (14). During the fatal infant idiopathic pulmonary haemorrhage outbreaks in the USA, isolated fungi were analysed for toxicity in vitro. S. chartarum produced cytotoxic and immunosuppressive macrocyclic trichothecenes (stachybotryotoxins) and spirocylic drimanes that caused inflammation and haemorrhages in the respiratory tract and intestines of laboratory animals. M. echinata produced griseofulvins and $A$. versicolor carcinogenic sterigmatocystin (15). Toxins produced by stachybotrys (satratoxins, roridins, verrucarins) affect the cell by binding to $60 \mathrm{~S}$ ribozomes, by inhibiting proteosynthesis, elongation, termination, and by inducing apoptosis, as they induce mitogen-activating proteinkinases (MAPK). Hintikka (16) also found that spirocyclic drimans of $S$. chartarum inhibited proteosynthesis and were immunosuppressive (inhibited the complement system and TNF-alfa release and stimulated plasminogen, fibrinolysis, and thrombolysis). Tobacco smoke was stressed by some epidemiologists as increasing the health risk of fungal toxins (14). S. chartarum isolated cardboard and vinyl ceilings of damp schools and dwellings in Denmark produced trichodermol trichothecenes (17). Acute intratracheal exposure of rats to atranone A, produced by $S$. chartarum isolated from mouldy walls in a Bratislava house, resulted in haematological changes, cell damage, and inflammatory pulmonary injury in those animals $(18,19)$. However, complex toxic mechanisms underlying the in vivo activity of atranones remain unclear. Simple trichothecens (such as trichodermol and trichodermin) that usually accompany atranones are neurotoxic (eye dysfunction, dyspnoea, tachycardia, nausea, tremors, dizziness, lowered concentration, confusion, loss of balance, hypotension, myelosupression, lower CNS activity bordering neurocognitive/behavioural deficits, and somnolence) and act as skin irritants (20).

In mice, Ren et al. (21) reported the adverse effects of mutagenic and foetotoxic mycotoxin alternariol and its monomethylether produced by Alternaria alternata isolated from ceiling tiles. This isolate was also able to grow on cardboard. An experimental culture of Penicillium expansum grown on wallpaper glue produced nephrotoxic citrinin and fagocytosis- 
inhibiting patulin (22). Metabolite synthesis in fungi depends on the quality of construction materials (23, 24). In our earlier study (25) on tracheal cultures of 1-day-old chicks, varying ciliostatic activity was found in biomass extracts from building materials (mineral wool, plasterboard, cardboard) inoculated with pure isolates of indoor moulds Penicillium chrysogenum, P. palitans, Trichoderma viride, Stachybotrys sp., and A. versicolor. Generally, moulds growing on materials composed of finely divided cellulose were more active than those growing on mineral wool. The only available data on the ciliostatic activity of indoor mould metabolites refer to sterigmatocystin from $A$. versicolor and Chaetomium spp. even though $78 \%$ of all indoor fungi (Aspergillus clavatus, A. flavus, A. fumigatus, A. nidulans, A. niger, A. ochraceus, A. restrictus, A. ustus, A. versicolor, Alternaria sp., Chaetomium sp., Cladosporium cladosporioides, $C$. sphaerospermum, Phoma sp., and Stachybotrys chartarum) isolated in Slovakia over the last 15 years produce complex metabolites capable of stopping tracheal ciliary beating in 24 hours (26-28). Viable spores of A. versicolor and Penicillium sp. were isolated from different plasters after 40 days to 3 months $(7,8)$, which means that they are able to produce toxins for a relatively long time.

Only a few animal studies addressed histological pulmonary changes after intranasal exposure to fungal spores and the time course of inflammatory and cytotoxic processes in the airways after intratracheal instillation of sporal suspensions $(20,29,30)$. All toxic fungal metabolites are located in micromycetal propagules (endometabolites), in aerosol, detritus, and house dust (exometabolites) (6). It is highly probable that hyphal fragments, dust, and material particles able to reach the alveoli have the highest depository and toxic potential. Most of the fungal spores are entrapped by the upper respiratory tract and do not reach further than the bronchi, because of their size, morphology, and the mode of propagation (slime heads, aggregation, etc.). This is why studies of the toxic effects of fungal spores prefer direct use of metabolite mixtures over recreating real exposure to microorganisms.

Health damaging effects of fungal haemolysins (indoor e. g. stachylysin produced by S. chartarum,or chrysolysin by Penicillium chrysogenum) result from the activation of histamine- and cytokin-producing cells (inflammatory, cold-like SBS symptoms) and from vascular tissue lysis (headaches, bleeding, vertigo) (31).

\section{CONCLUSIONS}

In the occupants of damp mouldy dwellings, complex toxic fungal metabolites can disrupt the selfcleaning airway system, induce inflammation, and damage cells and blood. These effects are enhanced by indoor contaminants such as cigarette smoke and can finally result in ill health including respiratory disorders and general intoxication, especially in children with quick metabolism. To determine the relationship between mycotoxins, their real mixtures, and other bio-, and non-biological factors in indoor environment and specific human health disorders after their inhalation, it is necessary to establish the minimal effective concentration of mycotoxin able to cause clinical symptoms, as opposed to the in vitro approach, to choose the best animal or other biological model for studying mycotoxin pathogenicity and pathophysiology (pulmonary deposition), and to characterise short- and long-term health damages (biomarkers) in the exposed people. Future studies should not neglect the potential of fungal toxins to cause multifactorial human diseases (immune, degenerative, and tumorous), whose incidence and prevalence are on the rise in modern societies.

\section{REFERENCES}

1. Kröling P. [Sick Building Syndrom. Symptome, Ursachen, und Prophylaxe gebäudebedingter Gesundheitsstörungen, in German].Allergologie 1998;21:180-91.

2. Burge PS. Sick building syndrome. Occup Environ Med 2004;61:185-90.

3. Yang G-H, Jarvis, BB, Chung Y-J, Pestka JJ. Apoptosis induction by satratoxins and other trichothecene mycotoxins: Relatinship to ERK, p38 MAPK, and SAPK/JNK activation. Toxicol Appl Pharmacol 2000;164:149-60.

4. Jaakkola MS, Piipari R, Jaakkola JJK. Occupation and asthma: A populatin-based incident case-control study. Am J Epidemiol 2003;158:981-7.

5. Crook B, Burton NC. Indoor moulds, sick building syndrome and building related illness. Fungal Biol Rev 2010;24:10613.

6. Piecková E, Wilkins K. Airway toxicity of house dust and its fungal composition. Ann Agric Environ Med 2004;11:6773.

7. Piecková E, Jesenská Z. Štúdium mykotickej kontaminácie omietok in vitro [Evaluation of in vitro fungal contamination of plasters, in Slovak]. Hygiena 2000;45:37-41.

8. Piecková E, Pivovarová Z, Sternová Z, Droba E. Building materials vs. fungal colonization - model experiments. In: Brebbia CA, editor. Environmental Health Risk IV. Southampton: WitPress; 2007. p. 71-8. 
9. Garrett MH, Rayment PR, Hooper MA, Abramson MJ, Hooper BM. Indoor airborne fungal spores, house dampness and associations with environmental factors and respiratory health in children. Clin Exp Allergy 1998;28:459-67.

10. Hendry KM, Cole EC. A review of mycotoxins in indoor air. J Toxicol Environ Health 1993;38:161-82.

11. Larsen FO, Clementsen P, Hansen M, Maltbaek N, OstenfeldtLarsen T, Nielsen KF, Gravesen S, Skov PS, Norn S. Volatile organic compounds from the indoor mould Trichoderma viride cause histamine release from human bronchoalveolar cells. Inflamm Res 1998;47(Suppl 1):S5-6.

12. Korpi A, Pasanen A-L, Pasanen P, Kalliokoski P. Microbial growth and metabolism in house dust. Int Biodeterior Biodegrad 1997;40:19-27.

13. Perry LP, Iwata M, Tazelaar HD, Colby TV, Yousem SA. Pulmonary mycotoxicosis: A clinicopathologic study of three cases. Mod Pathol 1998;11: 432-6.

14. Kuhn DM, Ghannoum MA. Indoor mold, toxigenic fungi, and Stachybotrys chartarum: Infectious disease perspective. Clin Microbiol Rev 2003;16:144-72.

15. Andersen B, Nielsen KF, Jarvis B. Characterisation of morphologically, chemically and physiologically different Stachybotrys species from water-damaged buildings. Mycologia 2002;94:392-403.

16. Hintikka E-L. The role of Stachybotrys in the phnomenon known as sick building syndrome. In: Straus DC, editor. Advances in applied microbiology. Vol 55. San Diego: Elsevier Academic Press; 2004. p. 155-73.

17. Nielsen KF, Hansen MO, Larsen TO, Thrane U. Production of trichothecene mycotoxins on water damaged gypsum boards in Danish buildings. Int Biodeterior Biodegrad 1998;42:1-7.

18. Piecková E, Hurbánková M, Černá S, Pivovarová Z, Kováčiková Z. Pulmonary cytotoxicity of secondary metabolites of Stachybotrys chartarum (Ehrenb.) Hughes. Ann Agric Environ Med 2006;13:259-62.

19. Piecková E, Hurbánková M, Černá S, Lišková A, Kováčiková Z, Kolláriková Z, Wimmerová S. Inflammatory and haematotoxic potential of indoor Stachybotrys chartarum (Ehrenb.) Hughes metabolites. Arh Hig Rada Toksikol 2009;60:401-9.

20. Rao CY, Burge HA, Brain JD. The time course of responses to intratracheally instilled toxic Stachybotrys chartarum spores in rats. Mycopathologia 2000;149:27-34.

21. Ren P, Ahearn DG, Crow Jr SA. Mycotoxins of Alternaria alternata produced on celing tiles. J Ind Microbiol Biotechnol 1998;20:53-4

22. Gravesen S, Frisvad JC, Samson RA. Microfungi. Copenhagen: Munksgaard; 1994.

23. Nielsen KF, Thrane U, Larsen TO et al. Production of mycotoxins on artificially inoculated building materials. Int Biodeter Biodegrad 1998;42:9-16.

24. Gravesen S, Nielsen PA, Iversen R, Nielsen KF. Microfungal contamination of damp buildings - examples of risk constructions and risk materials. Environ. Health Perspect 1999;107(Suppl 3):505-8

25. Wilkins K, Piecková E. Detection of ciliostatic activity in fungal growth on building materials. Environ Sci Pollut Res 2002;9:105-6.

26. Jesenská Z, Bernát D. Efects of mycotoxins on in vitro movement of tracheal cilia from one-day-old chicks. Folia Microbiol 1994;39:155-8.

27. Piecková E. In vitro toxicity of indoor Chaetomium Kunze ex Fr. Ann Agric Environ Med 2003;10:9-14.

28. Piecková E, Kunová Z. Indoor fungi and their ciliostatic metabolites. Ann Agric Environ Med 2002;9:59-63.

29. Nikulin M, Reijula K, Jarvis BB, Hintikka E-L. Experimental lung mycotoxicosis in mice induced by Stachybotrys atra. Int J Exp Pathol 1996;77:213-8.

30. Nikulin M, Reijula K, Jarvis BB, Veijalainen P, Hintikka EL. Effects of intranasal exposure to spores of Stachybotrys atra in mice. Fundam Appl Toxicol 1997;35:182-8.

31. Vesper SJ, Magnuson ML, Dearborn D, Yike I, Haugland RA. Initial characterization of the hemolysin stachylysin from Stachybotrys chartarum. Infect Immunol 2001;69:9126. 


\section{Sažetak}

\section{ŠTETNI ZDRAVSTVENI UČINCI PLIJESNI UNUTARNJIH PROSTORA}

Bolesti povezane sa stanovanjem te sindrom bolesne zgrade (engl. sick building syndrome, SBS), kao jedan od njihovih tipičnih primjera, povezani su s boravkom u zgradama s lošom kvalitetom zraka. Premda još nije uspostavljena jasna uzročno-posljedična povezanost, važnu ulogu u spomenutom fenomenu ima rast plijesni u unutarnjim prostorima. Pojavnost simptoma sindroma bolesne zgrade snažno ovisi o vlažnosti prostora. U metabolite plijesni koji mogu izazvati poremećaje zdravlja u osjetljivijih ispitanika ubrajamo beta-D-glukan, mikotoksine te hlapljive organske spojeve koji su poznati kao iritansi i/ili imunomodulatori. Toksični metaboliti gljiva unutarnjih prostora mogu biti sadržani u propagulama mikromiceta (endometaboliti), (bio)aerosolu, detritusu te kućnoj prašini (egzometaboliti). Najjači potencijal za depoziciju te toksični potencijal imaju fragmenti hifa, prašina i čestice koje mogu doprijeti do alveola. Većinu gljivičnih spora zaustave gornji dišni putovi te one zbog svoje veličine, morfologije i načina razmnožavanja (npr. ljepljive glavice i agregacija) ne dopiru dalje od bronha. To je razlog zašto se u istraživanjima toksičnih učinaka gljivičnih spora češće primjenjuju smjese metabolita negoli oponaša stvarna izloženost. Kronična izloženost niskim razinama smjesa gljivičnih toksikanata i drugih stresora unutarnjih prostora može izazvati sinergijske učinke i dovesti do teških neuroendokrino-imunosnih promjena.

KLJUČNE RIJEČI: dišni putovi, hlapljivi organski spojevi, mikotoksini, sindrom bolesne zgrade, upala

\section{CORRESPONDING AUTHOR:}

Elena Piecková

Medical Faculty, Slovak Medical Unviersity

Limbová 12, SK-833 03 Bratislava, Slovakia

E-mail: elena.pieckova@szu.sk 